\title{
Desain Sistem Charger untuk Baterai berkapasitas 650 mAh Menggunakan Sel Surya
}

\section{Design of Charger System for $650 \mathrm{mAh}$ Batteries Using Solar Cells}

\author{
Rahmi Mudia Alti ${ }^{1}$, Fiqri Wijaya Kusuma ${ }^{2}$, R. Evi Sovia ${ }^{3}$ \\ $1,2,3$ Universitas Nurtanio \\ J1. Pajajaran no.219, Lanud Husein S, Bandung \\ rahmimudia68@unnur.ac.id ${ }^{1}$
}

\begin{abstract}
Abstrak - Alat charger untuk baterai berkapasitas 650 mAh menggunakan sel surya merupakan uji coba alat yang digunakan untuk charger baterai berkapasitas 650 mAh menggunakan energi matahari. Baterai 650 mAh ini digunakan pada drone. Alat charger menggunakan sel surya ini digunakan sebagai alternatif pengisian energi pada baterai. Alat ini dirancang dengan menggunakan resistor, kapasitor, dioda, saklar, baterai $650 \mathrm{mAh}$, LED, sel surya, IC lm317, dan trimpot. Perangkat berupa sistem analog yang menggunakan voltage drop dan memanfaatkan step up \& step down serta LED sebagai indikasi pengisian. Hasil uji fungsi dilakukan dengan cara mengukur intensitas cahaya menggunakan alat lux meter, baik pada saat beroperasi maupun tidak untuk mengetahui nilai intensitas cahaya. Masing-masing panel menghasilkan keluaran tegangan rata-rata 6 Volt DC dengan arus 200mA. Untuk memenuhi kekurangan tegangan, keluaran panel surya dimasukan terlebih dahulu ke modul DC-DC Step Up. Dari modul Step Up tersebut dihasilkan tegangan keluaran sebesar 12 VDC yang kemudian dipakai oleh modul charger untuk melakukan pengisian baterai Lithium-ion Polymer (LIPO). Waktu yang efektif untuk proses pengisian baterai menggunakan sel surya adalah pada waktu siang hari sekitar pukul 11.00 sampai pukul 13.00. Dari hasil uji fungsi yang dilakukan, alat bekerja dengan baik yang ditandai dengan LED berwarna merah yang mengindikasikan sedang terjadinya proses charging. Dengan demikian, alat ini bisa dimanfaatkan sebagai pengisian energi alternatif pada drone yang menggunakan LIPO yang memiliki keterbatasan waktu terbang.
\end{abstract}

Kata Kunci: Charger, Sel Surya, Baterai.

\begin{abstract}
The charger for a battery with a capacity of $650 \mathrm{mAh}$ using solar cells is one of tools used for a battery charger with a capacity of $650 \mathrm{mAh}$ using solar energy that commonly used in drones. This solar cell is as an alternative charging energy for the battery. This charger is designed using resistors, capacitors, diodes, switches, 650 mAh battery, LEDs, solar cells, IC LM317, and trimpot. An analog system based on a voltage drop and utilizes step up \& step down and LEDs was used as an indication of charging. The testing was carried out by measuring the light intensity using a lux meter, both during operation and not to determine the value of light intensity. Each panel produces an average voltage output of 6volt DC with a current of 200mA. To meet the shortage of voltage, the output of the solar panel is first entered into the DC-DC Step Up module. From the Step Up module, an output voltage of 12 VDC is generated which is then used by the charger module to charge the Lithium-ion Polymer (LIPO) battery. The effective time for the battery charging process using solar cells is during the daytime around 11.00 to 13.00 . From the results of the function test carried out, the tool works well which is marked by a red LED which indicates the
\end{abstract}

TELKA, Vol.6, No.2, November 2020, pp. 138 146

ISSN (e): 2540-9123

ISSN (p): 2502-1982 
charging process is occurring. Thus, this tool can be used as alternative energy charging for drones that use LIPO which has limited flight time.

Keywords: Charger, Solar Cell, Battery.

\section{Pendahuluan}

Matahari merupakan sumber energi utama dan tidak terbatas untuk kehidupan. Dalam satu jam, jumlah energi dari matahari yang menghantam bumi lebih dari yang dikonsumsi seluruh dunia dalam satu tahun [1]. Singkatnya, dari Departemen Energi AS: Setiap jam, 430 quintillion Joule energi dari matahari menghantam bumi (1 quintillion Joule $=10^{18}$ joule) [1]. Perkembangan teknologi tenaga surya dianggap menjadi salah satu dari banyak solusi utama untuk memenuhi permintaan energi di seluruh dunia yang terus meningkat [2]. Secara teoritis, energi matahari memiliki potensi yang dapat dimanfaatkan untuk memenuhi kebutuhan energi seluruh dunia jika teknologi untuk memanen energi tersebut tersedia [3]. Saat ini telah banyak dikembangkan teknologi untuk memanen energi matahari (solar energy harvesting) seperti pemanfaatan energi matahari di atap dan fasad dalam lanskap perkotaan [4], potensi penggunaan energi matahari dalam siklus pendinginan dessicant [5], helm charger berbasis sel surya [6], charger handphone berbasis sel surya [7], charger baterai menggunakan sel surya [8] [9] [10] [11], energizer baterai surya [12] dan lain sebagainya.

Pada penelitian ini, sel surya dimanfaatkan pada alat charger untuk baterai berkapasitas 650 mAh yang digunakan pada drone. Drone merupakan sebuah kendaraan udara tanpa awak. Bentuk drone menyerupai pesawat terbang atau juga helikopter dalam ukuran kecil yang dapat di operasikan tanpa dikendarai oleh awak atau pilot. Alat canggih ini menggunakan remote control yang digunakan untuk mengontrol drone saat terbang di udara. Drone bisa dimanfaatkan pada area yang membahayakan untuk menemukan korban bencana alam, memantau area perbatasan suatu negara, membantu perawatan infrastruktur, mengawasi area persawahan, kepentingan jurnalisme, penelitian, perfilman, [13] dan sebagainya. Penggunaan drone selama ini menggunakan baterai Lithium-ion Polymer (LIPO) yang memiliki keterbatasan waktu terbang. Oleh karena itu dibutuhkan suatu rancangan alat yang dapat digunakan untuk mempermudah dalam pengisian ulang baterai pada drone dengan memanfaatkan energi matahari yang ditangkap melalui sel surya.

\section{Metode Penelitian}

\subsection{Perancangan Sistem}

Skema sistem tergambar pada blok diagram sistem. Blok diagram ini memudahkan proses pembuatan dan memahami sistem kerja alat. Blok diagram menjelaskan prinsip kerja secara detail dari alat yang disajikan pada Gambar 1.

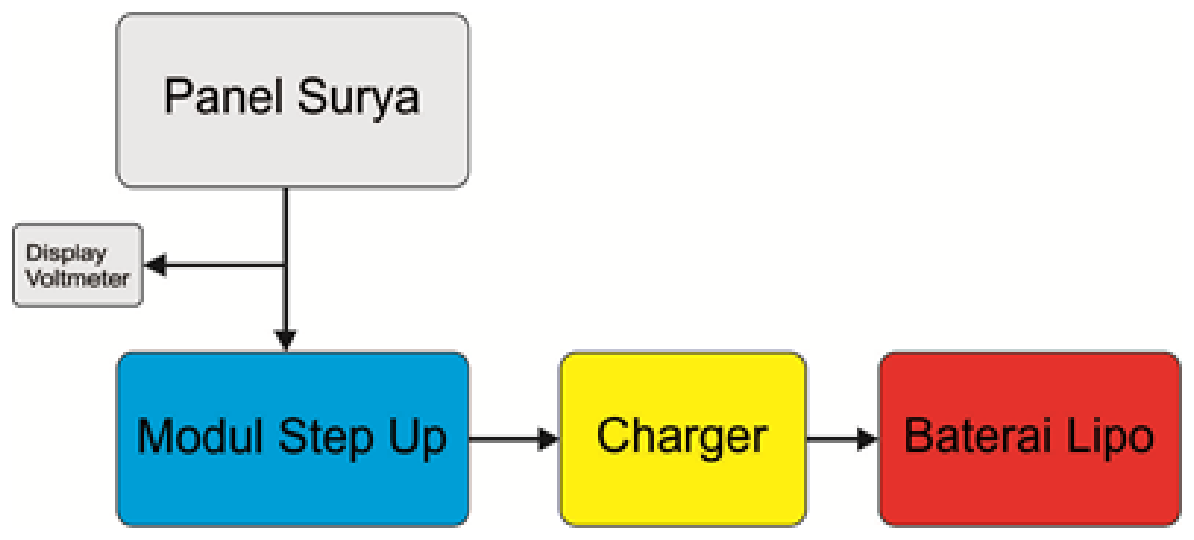

Gambar 1. Block diagram. 
a. Panel Surya

Secara prinsip panel surya adalah sebuah elemen semikonduktor yang dapat mengkonversi energi surya menjadi energi listrik dengan prinsip fotovoltaik [14].

b. Modul Boost Converter

Boost konverter adalah step up konverter atau konverter DC-DC dengan tegangan output yang lebih besar dari tegangan input. Konverter ini terdiri dari dua semikonduktor yaitu diode dan transistor. Daya untuk boost konverter bisa datang dari sumber DC yang cocok seperti baterai.

c. Charger

Charger atau pengisi baterai adalah pIranti yang digunakan untuk mengisi energi ke dalam baterai (isi ulang) dengan memasukkan arus listrik melaluinya. Arus listrik yang dimasukkan tergantung pada teknologi dan kapasitas baterai yang diisi ulang tersebut. Contohnya, arus yang diterapkan pada baterai mobil $12 \mathrm{~V}$ akan sangat berbeda dengan arus untuk baterai ponsel.

d. Baterai Lipo

Baterai Lipo atau baterai litium ion polimer adalah jenis baterai yang banyak digunakan untuk perangkat elektronik portable. Baterai Litium Polimer memiliki daya penghantar yang sangat cepat dan menyimpan elektrolit polimer yang padat. Baterai LIPO tidak menggunakan cairan sebagai elektrolit melainkan menggunakan elektrolit polimer kering yang berbentuk seperti lapisan plastik film tipis. Lapisan film ini disusun berlapis-lapis diantara anoda dan katoda yang mengakibatkan pertukaran ion [15]

e. Display voltmeter

Display Voltmeter adalah penampil dari alat ukur yang digunakan untuk mengukur besaran tegangan atau beda potensial listrik antara dua titik pada suatu rangkaian listrik yang dialiri arus listrik.

\subsection{Desain Sistem}

\subsubsection{Schematic Diagram Alat Charger untuk Baterai berkapasitas $650 \mathrm{mAh}$ Menggunakan Sel Surya}

Schematic diagram merupakan suatu gambar teknik yang menggambarkan suatu rangkaian elektronik dengan menggunakan simbol komponen elektronik. Dalam schematic diagram simbolsimbol tersebut dihubungkan dengan garis yang menggambarkan hubungan atau koneksi dari komponen tersebut di dalam rangkaian.

Dengan adanya schematic diagram cara kerja dari suatu alat atau sistem dapat diamati mulai dari input sampai output. Gambar schematic diagram alat dapat disajikan pada Gambar 2.

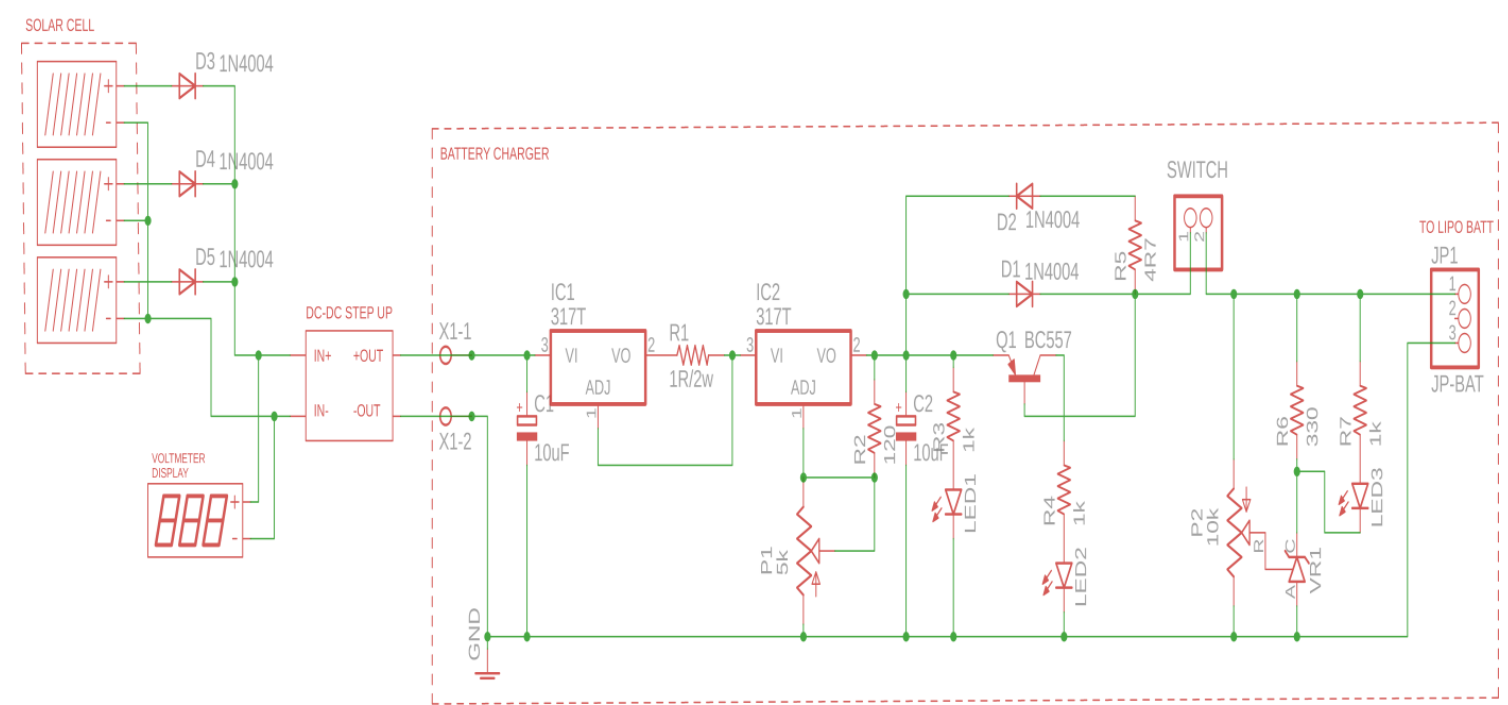

Gambar 2. Schematic diagram. 


\subsubsection{Proses Desain Schematic Diagram Menggunakan Software Autodesk Eagle}

Proses design schematic diagram mempermudah pembuatan papan PCB dan pemasangan komponen-komponen. Proses ini dirancang dengan menggunakan software Autodesk Eagle. Contoh pemilihan komponen dapat dilihat pada Gambar 3.

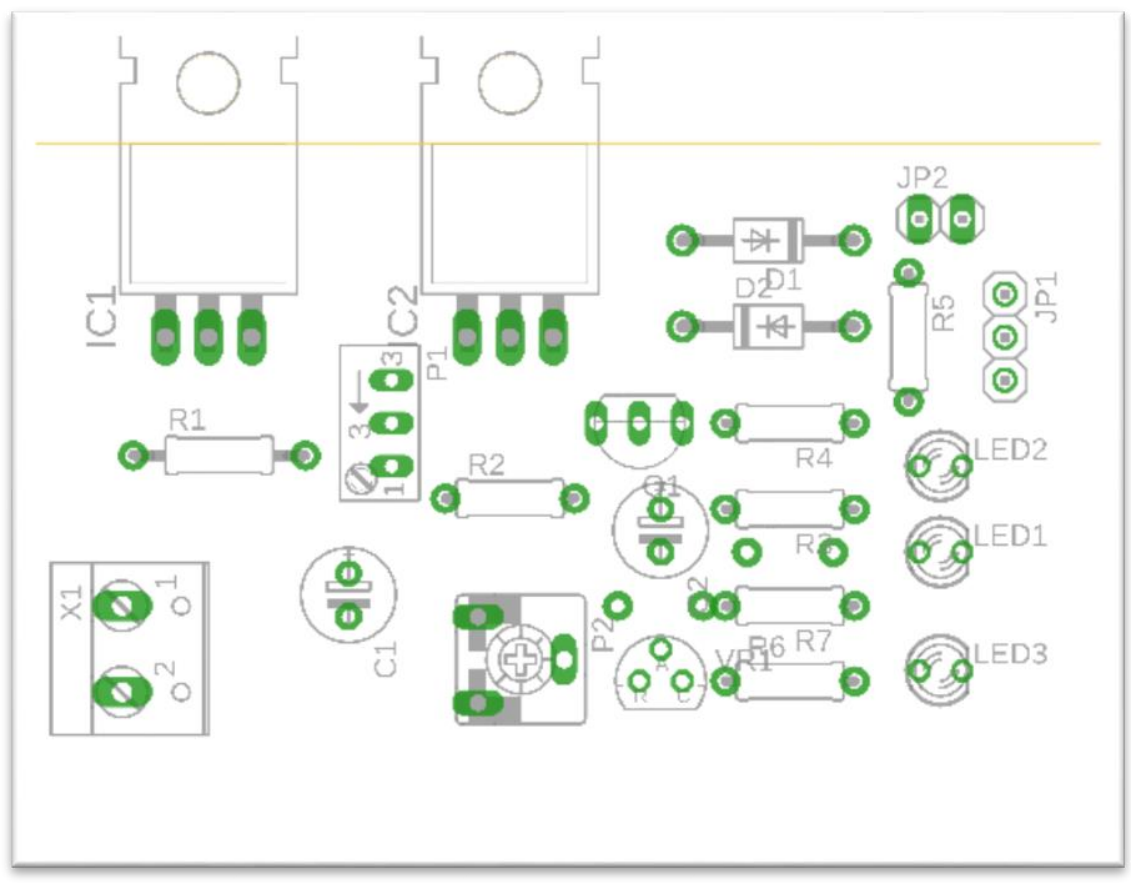

Gambar 3. Tampilan komponen software Autodesk Eagle.

Setelah komponen yang digunakan sudah dimasukkan, komponen lalu disambungkan dengan suatu garis serta diatur posisinya serapih mungkin. Hasil final schematic diagram disajikan pada Gambar 4.

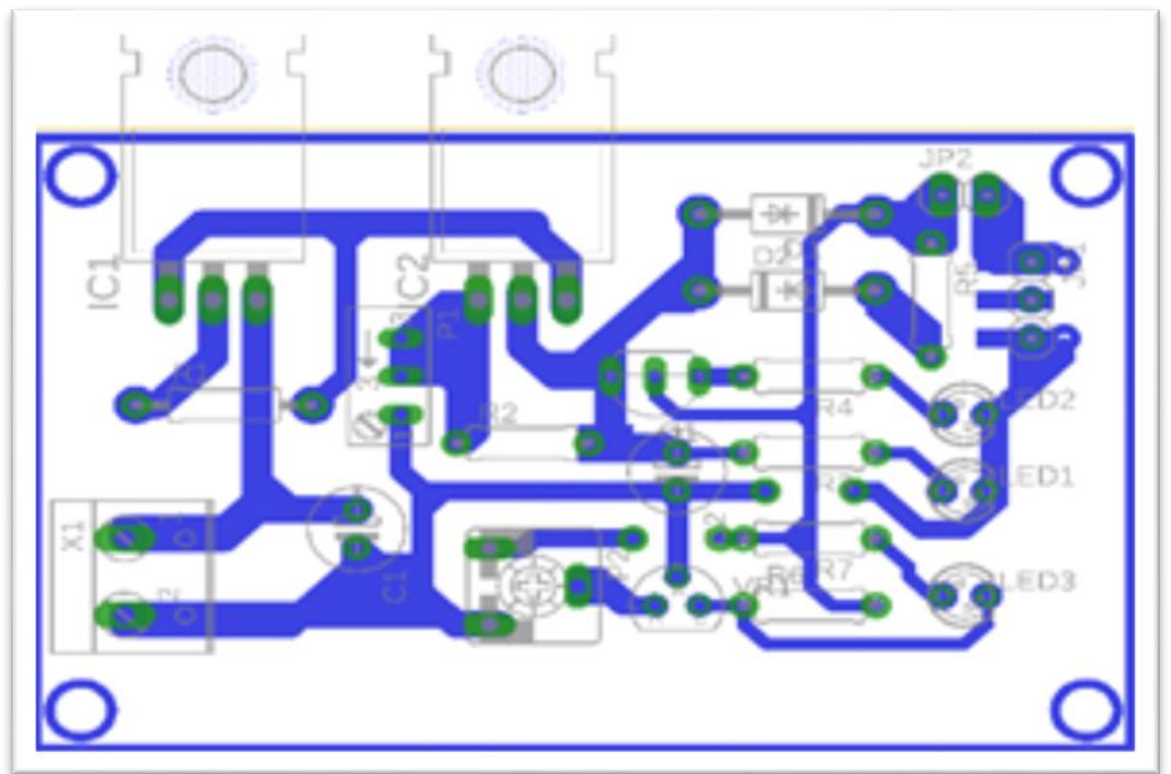

Gambar 4. Schematic diagram final. 


\subsection{Pembuatan Purwarupa}

\subsubsection{Pemasangan Komponen Alat}

Alat ini menggunakan beberapa komponen sesuai dengan schematic diagram. Adapun komponen-komponen dari alat ini, dipasang dan disolder sesuai dengan tata letaknya sesuai dengan Gambar 4, dan hasilnya dapat dilihat pada Gambar $5 .$.

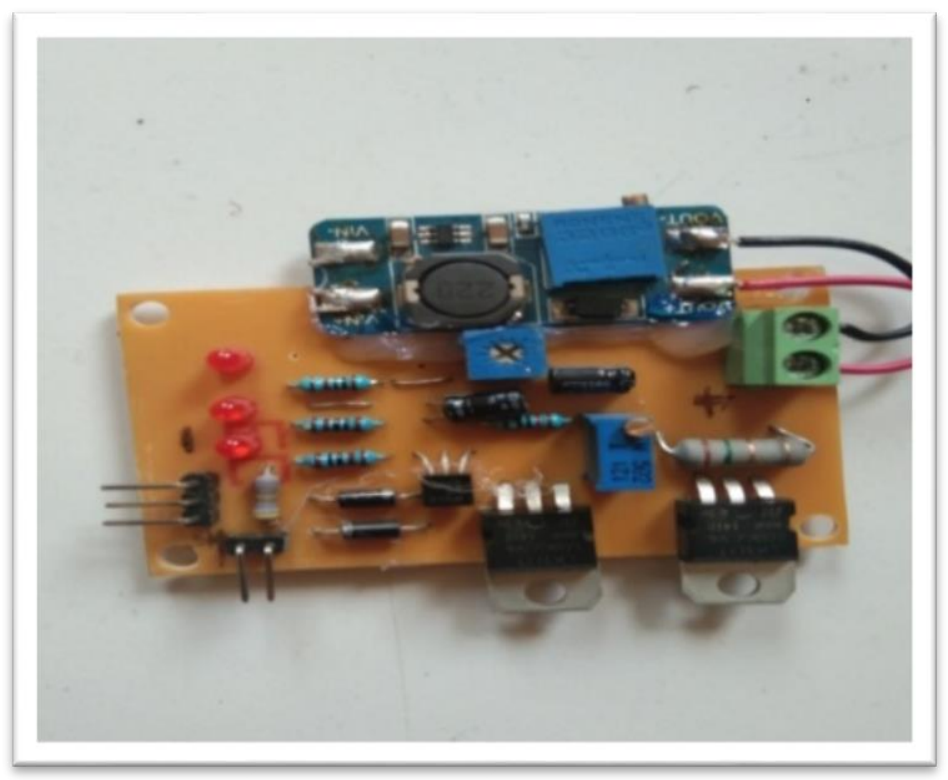

Gambar 5. Tampilan hasil pemasangan komponen pada PCB.

Komponen-komponen yang digunakan untuk pembuatan alat dapat dilihat pada Tabel 1 .

\begin{tabular}{cc}
\multicolumn{2}{c}{ Tabel 1. Komponen yang digunakan. } \\
\hline Nama Komponen & Jumlah \\
\hline Solar cell & 2 \\
Modul step up & 1 \\
Dioda & 6 \\
LM317 T & 2 \\
Resistor & 6 \\
Led & 3 \\
TR BC557 & 1 \\
Kapasitor elektrolit & 2 \\
Trimpot & 2
\end{tabular}

\subsubsection{Pengemasan Alat}

Setelah dilakukan pemasangan, maka tahap selanjutnya dilakukan pengemasan. Pengemasan bermaksud agar komponen-komponen yang digunakan tertata rapih sesuai dengan yang diinginkan dan bahan acrylic digunakan sebagai box.

Pengemasan komponen dalam box dapat dilihat pada Gambar 6 untuk tampak depan, Gambar 7 untuk tampak samping kanan, Gambar 8 untuk tampak samping kiri, dan Gambar 9 untuk tampak atas. 


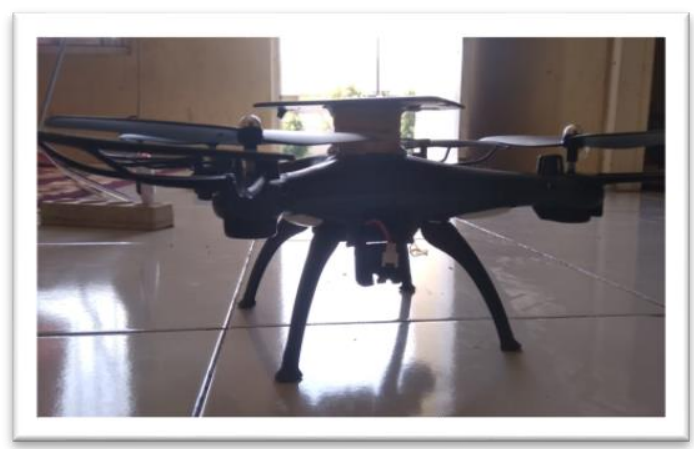

Gambar 6. Alat tampak depan.

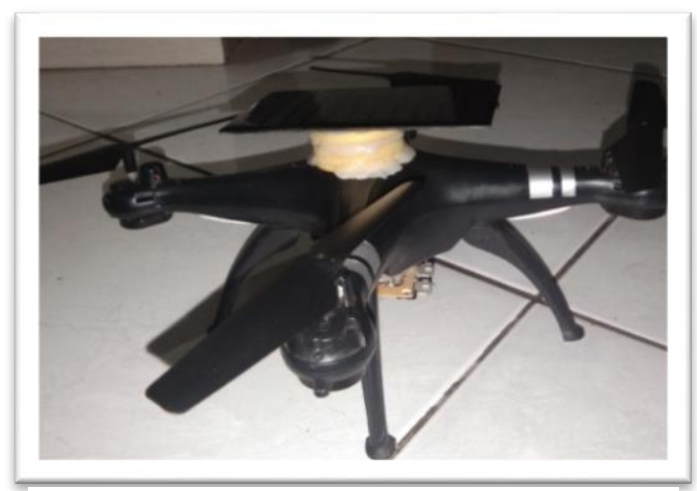

Gambar 8. Alat tampak samping kiri.

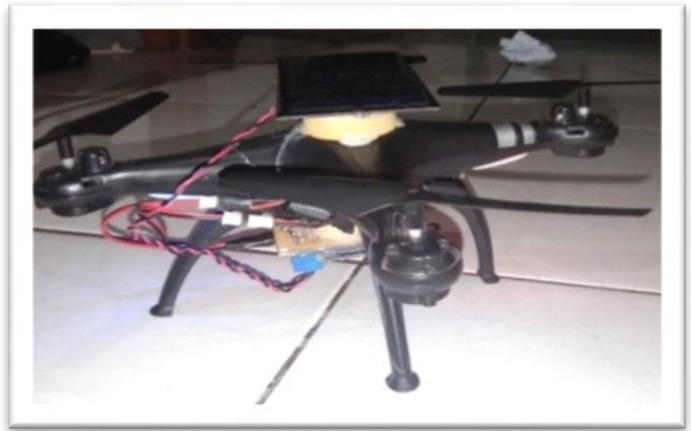

Gambar 7. Alat tampak samping kanan.

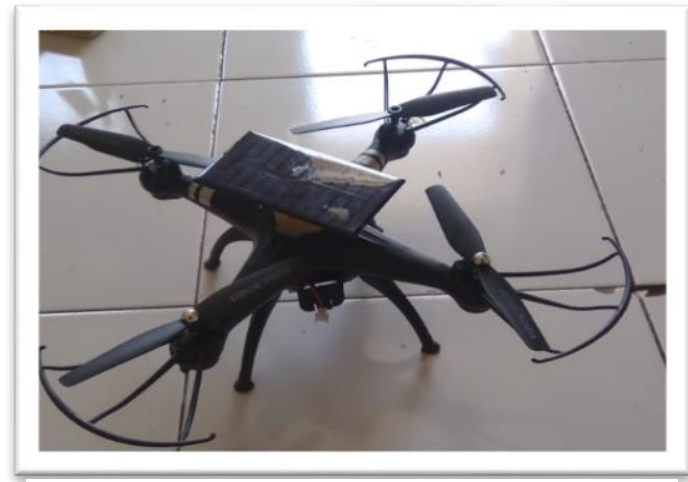

Gambar 9. Alat tampak atas.

\subsection{Uji Fungsi}

Setelah proses pembuatan alat selesai, maka tahap selanjutnya adalah tes uji fungsi yang berfungsi untuk mengetahui apakah alat tersebut dapat digunakan sesuai fungsinya. Proses uji fungsi dilakukan dengan menghubungkan catu daya ke rangkaian. Jika beban dapat berfungsi sesuai dengan mestinya, maka uji fungsi dianggap berhasil.

\section{Hasil dan Pembahasan}

Alat bekerja dengan merubah energi radiasi sinar matahari menjadi energi listrik yang kemudian akan dipakai untuk melakukan pengecasan pada baterai Lipo. Setelah alat uji coba dinyalakan maka sel surya akan mendeteksi energi radiasi sinar matahari yang kemudian digunakan untuk mengubah radiasi sinar matahari tersebut menjadi energi listrik sebagai input untuk proses charging pada baterai.

Energi radiasi dari sinar matahari ditangkap menggunakan panel surya. Masing-masing menghasilkan keluaran tegangan rata-rata 6volt DC dengan arus 200mA. Untuk mendapatkan arus yang lebih besar, beberapa panel surya dihubungkan keluarannya secara paralel. Sebelum keluaran panel surya digabungkan, ditambahkan diode sebagai pencegah arus balik. Spesifikasi baterai Lipo mengharuskan pengecasan dilakukan pada tegangan 8.4 VDC.

Untuk memenuhi kekurangan tegangan, keluaran panel surya dimasukan terlebih dahulu ke modul DC-DC Step Up. Dari modul Step Up tersebut akan dihasilkan tegangan keluaran sebesar 12 VDC yang kemudian akan dipakai oleh modul charger untuk melakukan pengisian baterai Lipo. Apabila intensitas kurang dari yang dibutuhkan, maka sel surya akan mendeteksi kembali energi radiasi sinar matahari tersebut hingga sesuai dengan yang dibutuhkan untuk proses charging. Apabila telah memenuhi, maka proses charging akan terlaksana hingga baterai penuh. 


\subsection{Uji Fungsi Alat}

Uji fungsi alat ini dilakukan dengan cara menghubungkan sel surya dengan konektor pada rangkaian utama, apabila LED berwarna merah menyala maka proses charger berfungsi untuk mengisi baterai. Apabila kondisi LED tidak menyala maka proses charger tidak bisa untuk mengisi baterai.

Hasil uji fungsi dilakukan dengan cara mengukur intensitas cahaya menggunakan alat lux meter, baik pada saat beroperasi maupun tidak untuk mengetahui nilai intensitas cahaya. Untuk mengetahui lebih jelas dari fungsi uji coba alat charger menggunakan sel surya pada baterai berkapasitas $650 \mathrm{mAh}$ ini, dijelaskan pada subbab berikutnya.

\subsection{Percobaan Pertama Uji Fungsi Sel Surya}

Uji fungsi pada sel surya untuk mengetahui alat charger berfungsi dengan baik sesuai dengan yang diinginkan. Jika sel surya menerima masukan intensitas cahaya maka alat charger akan mengolah intensitas cahaya menjadi energi listrik. Proses pengukuran intensitas cahaya dapat dilihat pada Gambar 10 dan Tabel 3.

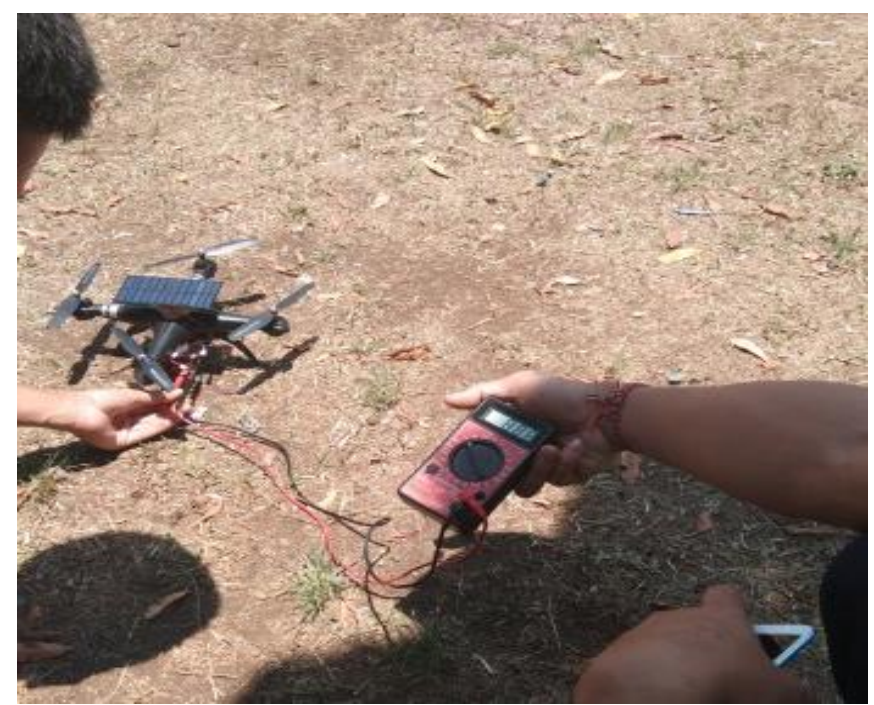

Gambar 10. Proses pengambilan intensitas cahaya.

Tabel 3. Waktu dan intensitas matahari.

\begin{tabular}{|c|c|c|c|c|}
\hline No & Tanggal & Satuan & Waktu & $\begin{array}{c}\text { Intensitas } \\
\text { Cahaya }(l x)\end{array}$ \\
\hline \multirow[t]{9}{*}{1} & Senin, 14 Oktober 2019 & Intensitas cahaya & 11.00 & 1157,4 \\
\hline & & $\left(\mathrm{W} / \mathrm{m}^{2}\right)$ & 11.15 & 1172,8 \\
\hline & & & 11.30 & 1152,2 \\
\hline & & & 11.45 & 1187,1 \\
\hline & & & 12.00 & 1165,3 \\
\hline & & & 12.15 & 1171,5 \\
\hline & & & 12.30 & 1156,4 \\
\hline & & & 12.45 & 1162,2 \\
\hline & & & 13.00 & 1148,2 \\
\hline \multirow[t]{9}{*}{2} & Selasa, 15 Oktober 2019 & Intensitas cahaya & 11.00 & 1198,5 \\
\hline & & $\left(\mathrm{W} / \mathrm{m}^{2}\right)$ & 11.15 & 1197,2 \\
\hline & & & 11.30 & 972,8 \\
\hline & & & 11.45 & 1184,1 \\
\hline & & & 12.00 & 973,8 \\
\hline & & & 12.15 & 869,2 \\
\hline & & & 12.30 & 955,1 \\
\hline & & & 12.45 & 1015,1 \\
\hline & & & 13.00 & 1152,4 \\
\hline
\end{tabular}




\begin{tabular}{|c|c|c|c|c|}
\hline No & Tanggal & Satuan & Waktu & $\begin{array}{c}\text { Intensitas } \\
\text { Cahaya }(l x)\end{array}$ \\
\hline \multirow[t]{9}{*}{3} & Rabu, 16 Oktober 2019 & Intensitas cahaya & 11.00 & 1168,2 \\
\hline & & $\left(\mathrm{W} / \mathrm{m}^{2}\right)$ & 11.15 & 1167,7 \\
\hline & & & 11.30 & 1174 \\
\hline & & & 11.45 & 1161,5 \\
\hline & & & 12.00 & 1160,2 \\
\hline & & & 12.15 & 1163,3 \\
\hline & & & 12.30 & 1161,7 \\
\hline & & & 12.45 & 1131,5 \\
\hline & & & 13.00 & 1124,3 \\
\hline
\end{tabular}

\subsection{Percobaan Kedua Uji fungsi Alat Charger}

Pada percobaan kedua, alat charger juga berfungsi dengan baik sesuai dengan yang diinginkan. Hasil uji fungsi disajikan pada Gambar 11.

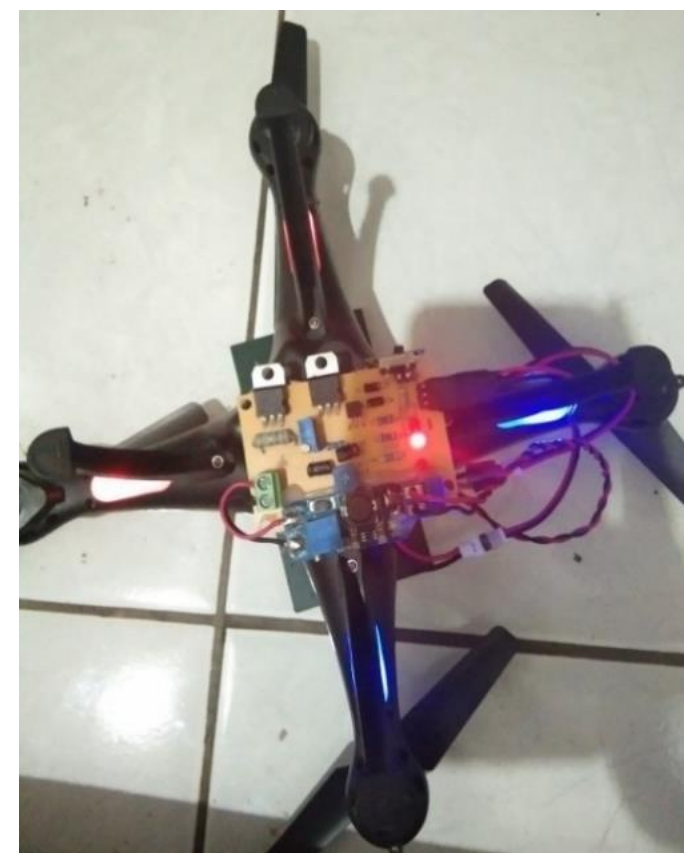

Gambar 11. Pengecekan alat charger dalam keadaan berfungsi.

\section{Kesimpulan}

Dalam pembuatan alat charger untuk baterai berkapasitas $650 \mathrm{mAh}$ menggunakan sel surya ini dapat ditarik beberapa kesimpulan sebagai berikut: 1). Uji coba alat charger untuk baterai berkapasitas $650 \mathrm{mAh}$ menggunakan sel surya ini telah terbukti mengubah radiasi sinar matahari menjadi energi listrik, 2). Pembuatan dan perancangan uji coba alat charger untuk baterai berkapsitas $650 \mathrm{mAh}$ menggunakan sel surya ini cukup mudah dan praktis untuk digunakan, 3). Alat charger ini merupakan sistem analog yang menggunakan Voltage drop dan memanfaatkan step up \& step down dan LED sebagai indikator pengisian, 4). Waktu yang efektif untuk proses pengisian baterai menggunakan sel surya adalah pada waktu siang hari.

\section{Referensi}

[1] R. Harrington, "https://www.businessinsider.com/," 29 September 2015. [Online]. Available: https://www.businessinsider.com/this-is-the-potential-of-solar-power-20159? $\mathrm{r}=\mathrm{US} \& \mathrm{IR}=\mathrm{T} \#: \sim:$ text=In\%20a\%20single $\% 20$ hour$\% 2 \mathrm{C} \% 20$ the, with $\% 2018 \% 20$ zeroes $\%$ 20after\%20it!. [Accessed Friday August 2020]. 
[2] E. Kabir, P. Kumar, S. Kumar, A. A. Adelodun and K.-H. Kim, "Solar energy: Potential and future prospects," Renewable and Sustainable Energy Reviews, no. 82, pp. 894-900, 2018.

[3] T. Blaschke, M. Biberacher, S. Gadocha and I. Schardinger, "Energy landscapes': Meeting energy demands and human aspirations," Biomasss and Bioenergy, vol. 55, pp. 3-16, 2013.

[4] P. Redweik, "Solar energy potential on roofs and facades in an urban landscape," Solar energy, pp. 332-341, 2013.

[5] H.-M. Henning, T. Erpenbeck, C. Hindenburgh and I. S. Santamaria, "The Potential of Solar Energy use in Dessicant Cooling Cycles," International Journal of Refrigeration, Vol.24, No.3, pp. 220-229, 2001.

[6] S. Fuada, "Helm Charger Tenaga Surya: Kajian Prospek Bisnis Berbasis Technopreneur," Kongres Ilmu Pengetahuan Nasional (KIPNAS) X, Jakarta, 2015.

[7] F. Bishay and M. M. Botros.United States Design Patent US D644,168 S, 2011.

[8] T. Nomi and S. Oda.United States Patent US D657,305S, 2012.

[9] N. Z. Elfani and P. Sasmoko, "Power Bank Portable Solar Charger Menggunakan Sistem Buckboost Converter Berbasis Mikrokontroler ATMEGA 32," Jurnal Gema Teknologi, Vol.18, no.4, pp. 15-20, 2016.

[10] I. Sumirat and R. R. Tugonggo, "Aplikasi Sel Surya Sebagai Energi Alternatif," Jurnal Teknik Elektro dan Sains, 2014.

[11] B. Anto, E. Hamdani and R. Abdullah, "Portable Battery Charger Berbasis Sel Surya," Jurnal Rekayasa Elektrika, Vol. 11, no.1, pp. 19-24, 2014.

[12] M. E. Thompson.United States Patent Patent 4,539,516, 1985.

[13] R. P. Putra, "eprints repository software," 2016. [Online]. Available: http://eprints.polsri.ac.id/3780/3/BAB\%20II.pdf. [Accessed 1 August 2020].

[14] D. Suryana and M. M. Ali, "Pengaruh Temperatur / Suhu Terhadap Tegangan," Jurnal Teknologi Proses dan Inovasi Industri, vol. 2, no. 1, pp. 49-52, 2016.

[15] M. T. Afif and I. A. P. Pratwi, "Analisis Perbandingan Baterai Lithium-Ion, LithiumPolymer" Jurnal Rekayasa Mesin, vol. 6, no. 2, pp. 95-99, 2015. 